\title{
触 New Disease Reports \\ First report of Dasheen mosaic virus in Zantedeschia in Bosnia and Herzegovina
}

\author{
S. Grausgruber-Gröger ${ }^{1 *}$, S. Richter ${ }^{2}$, J. Mihić Salapura ${ }^{3}$, D. Kovačić Jošić ${ }^{3}$, V. Trkulja $^{3}$ and H. Reisenzein $^{1}$
}

\begin{abstract}
${ }^{1}$ Austrian Agency for Health and Food Safety, Institute for Sustainable Plant Production, Spargelfeldstrasse 191, 1220 Vienna, Austria; ${ }^{2}$ Austrian Agency for Health and Food Safety, Institute for Veterinarian Disease Control, Robert Koch Gasse 17, 2340 Mödling, Austria; ${ }^{3}$ Agricultural Institute of Republic of Srpska, Knjaza Miloša 17, 78000 Banja Luka, Bosnia \& Herzegovina
\end{abstract}

*E-mail: sabine.grausgruber-groeger@ages.at

Received: 23 Jun 2015. Published: 16 Mar 2016.

In April 2013, yellowing and distortion of leaves as well as mosaic and chlorotic ring symptoms were observed on calla lilies (Zantedeschia sp.) in nurseries in Bosnia and Herzegovina (Fig. 1). The virus-like symptoms were present in several greenhouses in the vicinity of Banja Luka. Disease incidence was estimated to be between 10 and $20 \%$ of the 200 plants inspected. Since ornamental plant production is of great economic importance in that region, symptom-bearing plant leaves were collected, and a pooled sample was frozen and brought to the Institute for Sustainable Plant Production, Vienna for analysis.

Two subsamples were taken from the pooled sample and RNA was extracted using an RNeasy Plant Mini Kit (Qiagen, Hilden, Germany). RTPCR was done initially using two sets of primers. To test for Tomato spotted wilt virus (TSWV), primers S1 TSWV and S2 TSWV corresponding to a 297 bp region of the TSWV N gene (Mumford et al., 1996) were used. Screening for potyvirus infection was done using degenerate primers designed by Marie-Jeanne et al. (2000) which yield a 327 bp fragment of the potyvirus capsid gene. No TSWV was detected in either subsample but both were positive for potyvirus infection. The potyvirus amplicons from both subsamples were pooled and sequenced. Sequence comparison revealed $94 \%$ identity to a sequence of Dasheen mosaic virus (DsMV GenBank Accession Number AF048981). To obtain a longer amplification product from the DsMV coat protein gene the forward primer oligo 1n from Marie-Jeanne et al. (2000) was used in combination with primer DRO (Hu et al., 2010). The amplified fragment (581 bp) shared 93\% identity to DsMV (EF199550) and was submitted to NCBI (KP729477). Electron microscopy of symptomatic plant leaves was performed by negative staining. The grids were examined using a Zeiss 906 transmission electron microscope at $80 \mathrm{kV}$. Electron microscopy confirmed the presence of a

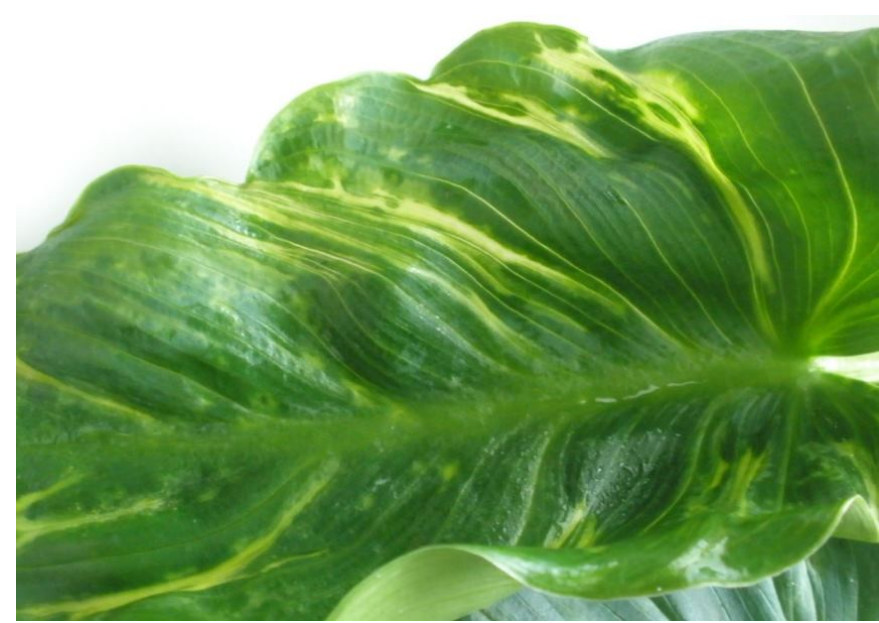

Figure 1 potyvirus (Fig. 2). The virions were non-enveloped with a flexuous and filamentous nucleocapsid, 650 to $850 \mathrm{~nm}$ long and $11-20 \mathrm{~nm}$ in diameter. No other virus particle type was found using electron microscopy.

It was not possible to trace back the original source of DsMV in the greenhouses concerned but all infected plants were destroyed to avoid further dissemination. To our knowledge this is the first report of DsMV in Bosnia and Herzegovina, and the first report of a virus infecting this host in the country.

\section{Acknowledgements}

This cooperation was done within the EC-funded project Twinning Light BA 09 IB AG 01 TWL (Strengthening of the capacities of the phytosanitary services in $\mathrm{BiH}$ ).

\section{References}

Hu WC, Huang CH, Lee SC, Wu CI, Chang YC, 2010. Detection of four calla potyviruses by multiplex RT-PCR using nad5 mRNA as an internal control. European Journal of Plant Pathology 126, 43-52. http://dx.doi.org/10.1007/s10658-009-9519-y

Marie-Jeanne V, Ioos R, Peyre J, Alliot B, Signoret P, 2000.

Differentiation of Poaceae potyviruses by reverse transcription-polymerase chain reaction and restriction analysis. Journal of Phytopathology 148, 141-151. http://dx.doi.org/10.1046/j.1439-0434.2000.00473.x

Mumford RA, Barker I, Wood KR, 1996. An improved method for the detection of Tospoviruses using the polymerase chain reaction. Journal of Virological Methods 57, 109-115.

http://dx.doi.org/10.1016/0166-0934(95)01975-8

Figure 2

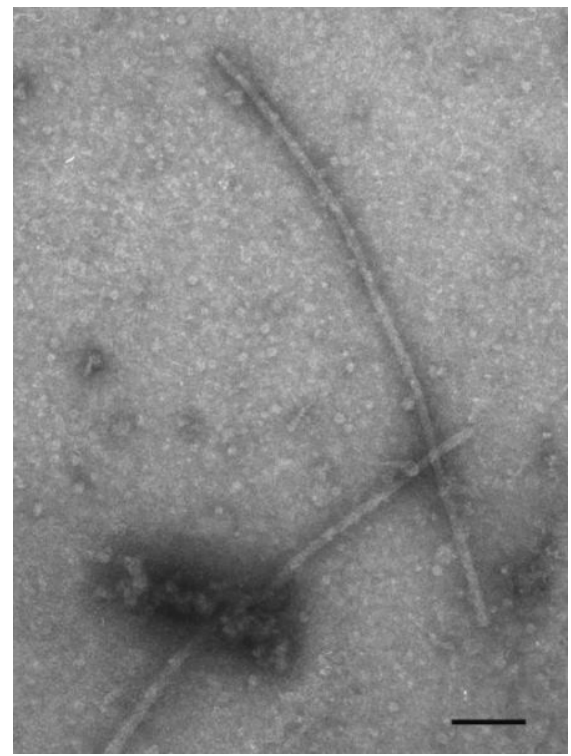

To cite this report: Grausgruber-Gröger S, Richter S, Mihić Salapura J, Kovačić Jošić D, Trkulja V, Reisenzein H, 2016. First report of Dasheen mosaic virus in Zantedeschia in Bosnia and Herzegovina. New Disease Reports 33, 13.

http://dx.doi.org/10.5197/j.2044-0588.2016.033.013 (c) 2016 The Authors

This report was published on-line at www.ndrs.org.uk where high quality versions of the figures can be found. 